\title{
PENGARUH PELATIHAN JARIMATIKA TERHADAP PENURUNAN TINGKAT STRESS BAGI NARAPIDANA LEMBAGA PEMASYARAKATAN (LAPAS) KELAS IIB RANGKAS BITUNG
}

\author{
Egi Adha Juniawan \\ STKIP La Tansa Mashiro \\ egiadha93@gmail.com
}

\begin{abstract}
ABSTRAK
Latar belakang kehidupan seorang narapidana Lapas kelas IIB Rangkasbitung merupakan stressor yang berat. Menjalani kehidupan yang tidak bebas, perasaan malu, sanksi sosial memperburuk dan mengintensifkan stressor sebelumnya. Mengingat peran Lapas sebagai tempat pembinaan maka hal tersebut harus segera ditangani guna mengoptimalkan fungsi dan tujuan Lapas itu sendiri. Dalam penelitian ini bertujuan untuk mengetahui efek atau manfaat dari pelatihan jarimatika dalam menangani tingkat stres yang terjadi pada narapidana, Penelitian ini menggunakan pendekatan quasi-eksperimen. Desain yang digunakan adalah control group design with pre-test and post-test yaitu desain eksperimen yang menggunakan dua kelompok yang terdiri dari kelompok kontrol dan kelompok eksperimen. Instrumen penelitian yang digunakan untuk memperoleh data setiap variabel adalah menggunakan tes dan angket. Responden dalam penelitian ini berjumlah 50 narapidana. Analisis data menggunakan teknik uji t yaitu paired sample t-test. Berdasarkan hasil temuan dalam penelitian ini menunjukkan bahwa hasil uji perbedaan skor pre-test dan post-test menunjukkan bahwa pelatihan jarimatika menunjukkan perbedaan signifikan pada kelompok eksperimen sebelum diberikan pelatihan dan setelah diberikan pelatihan. Disimpulkan bahwa pelatihan jarimatika memiliki kontribusi secara signifikan dalam memberikan perubahan terhadap penurunan tingkat stress pada narapidana.
\end{abstract}

Kata Kunci : Jarimatika, Narapidana, Stres.

\begin{abstract}
The background of the life of a prisoner class IIB Rangkasbitung prison is a severe stressor. Live a life that is not free, feelings of shame, social sanctions exacerbate and intensify previous stressors. Given the role of prisons as a place of guidance, this must be immediately addressed in order to optimize the function and purpose of prisons themselves. In this study aims to determine the effects or benefits of Jarimatika training in dealing with stress levels that occur in prisoners, this study uses a quasiexperimental approach. The design used is the control group design with pre-test and post-test, which is an experimental design that uses two groups consisting of a control group and an experimental group. The research instrument used to obtain data for each variable is to use tests and questionnaires. Respondents in this study were 50 inmates. Data analysis used the $t$ test technique, namely paired sample t-test. Based on the findings in this study indicate that the results of the test differences in the pre-test and post-test scores indicate that the Jarimatika training showed significant differences in the experimental group before being given training and after being given training. It was concluded that Jarimatika training had a significant contribution in providing changes in reducing the stress level of inmates.
\end{abstract}

Keywords: Jarimatika, Prisoners, Stress. 


\section{PENDAHULUAN}

Kriminalitas termasuk masalah sosial dan merupakan penyimpangan sosial dalam masyarakat. Berbagai tindakan kriminal sering dijumpai secara langsung dan tidak langsung, sebagaimana dapat dilihat dalam pemberitaan baik dari media cetak atau elektronik. Kriminalitas dapat dilakukan siapa saja, kapan saja dan di mana saja, termasuk oleh mereka yang masih tergolong anak-anak. Terkait dengan tingkat kriminal yang terjadi di Indonesia, kejahatan pada tahun 2018 Indonesia berada pada peringkat 68 dari 147 Negara dan kejahatan yang tercermin dari tahun ke tahun. Menurut Biro Pengendalian Operasi Mabes Polri yang dilangsir oleh BPS Kriminal tahun 2018 mencatat terjadi 336.652 tindak kejahatan di Indonesia. Total penghuni Lapas di seluruh Indonesia sebanyak 256.273 orang. Dari jumlah itu, 63 persen adalah kasus narkoba. Adapun kasus kejahatan teroris sebanyak 558 orang. Dari jumlah itu, 1.113 merupakan WNA (Sumber indeks numbeo.com).

Menurut Biro Pengendalian Operasi Mabes Polri yang dilangsir oleh BPS Kriminal tahun 2018 jumlah kejahatan yang menonjol tahun 2000-2017, yaitu: pembunuhan, penganiayaan, kesusilaan, penculikan, pencurian, narkotika, dan korupsi. Jumlah orang yang mengalami tindak kejahatan per100 ribu penduduk (crime rate) mencapai 129 orang. Provinsi yang melaporkan jumlah tindak kejahatan terbanyak terdapat di Sumatera Utara sebanyak 39.867 kasus. Ibukota Indonesia, DKI Jakarta menempati posisi selanjutnya dengan angka kejahatan yang dilaporkan ke Metro Jaya sebanyak 34.767 kasus. Sementara itu, provinsi yang melaporkan tindak kejahatan paling sedikit adalah Maluku sebanyak 789 kasus dan Sulawesi Barat sebanyak 1.841 kasus.

Kemenkumham RI melansir dari sejumlah lembaga pemasyarakatan yang tersebar di Indonesia (tahanan/napi) tiga tahun terakhir (2016-2018) lewat SDP (sistem database pemasyarakatan). Adapun jumlah tahanan/napi anak dan jumlah tahanan dan napi secara keseluruhan, yaitu: (1) tahun 2016 jumlah tahanan/napi 24.690 orang (tahanan 8.683 orang dan napi 16.007 orang); (2) tahun 2017 jumlah tahanan/napi 29.444 (tahanan 9.421 orang dan napi 20.023 orang); dan (3) tahun 2018 jumlah tahanan/napi 33.472 (tahanan 10.482 orang dan napi 22.990 orang). Dari jumlah penghuni LP sepanjang 2018, 50\% di antaranya hanya jebolan pendidikan dasar. Tidak lulus SD sebanyak 11\%, Hanya lulusan pendidikan dasar sebanyak 50\%, Lulusan SMA sebanyak 27\%, Sisanya Sarjana sebanyak 5.480 orang, Master sebanyak 695 orang dan Doktor sebanyak 56 orang. (sumber: smslap. ditjenpas.go.id). 
Berdasarkan Undang-undang Nomor 12 Tahun 1995 tentang Pemasyarakatan disebutkan bahwa Lembaga Pemasyarakatan yang selanjutnya disebut LAPAS adalah tempat untuk melaksanakan pembinaan Narapidana dan Anak Didik Pemasyarakatan. Sedangkan yang dimaksud dengan Narapidana adalah Terpidana yang menjalani pidana hilang kemerdekaan di LAPAS, sementara yang dimaksud dengan Terpidana adalah seseorang yang dipidana berdasarkan putusan pengadilan yang telah memperoleh kekuatan hukum tetap. Dengan demikian LAPAS berarti hanya berfungsi untuk melaksanakan pembinaan bagi Terpidana yang menjalani pidana hilang kemerdekaan. Sedangkan dalam sistem KUHP jenis pidana hilang kemerdekaan (Pasal $10 \mathrm{KUHP}$ ) adalah meliputi pidana penjara (baik pidana penjara seumur hidup maupun pidana penjara sementara) dan pidana kurungan. Ketentuan terhadap pelayanan Tahanan sudah ada peraturannya yaitu diatur dalam Peraturan Menteri Kehakiman Republik Indonesia Nomor M. 04. UM.01.06 Tahun 1983 tentang Tata Cara Penempatan, Perawatan Tahanan dan Tata Tertib Rumah Tahanan Negara.

Lembaga Pemasyarakatan adalah tempat untuk melaksanakan pembinaan Narapidana dan anak didik Pemasyarakatan. Narapidana adalah terpidana yang menjalani pidana hilang kemerdekaan di LAPAS. Dalam ketentuan Pasal 1 ayat (3) Undang-undang Nomor: 12 Tahun 1995 tentang Pemasyarakatan disebutkan bahwa: Lembaga Pemasyarakatan yang selanjutnya disebut LAPAS adalah tempat untuk melaksanakan pembinaan Narapidana dan Anak Didik Pemasyarakatan. Pengertian pembinaan secara umum adalah suatu proses penggunaan manusia, peralatan, uang, waktu, metode, dan sistem yang didasarkan pada prinsip tertentu untuk usaha mencapai tujuan yang telah ditentukan dengan daya guna dan hasil guna yang sebesar besarnya. Pengertian lain daripada "pembinaan" adalah segala usaha atau tindakan yang berhubungan langsung dengan perencanaan, penyusunan, pembangunan atau pengembangan, pengarahan, penggunaan serta pengendalian sesuatu secara berdaya guna dan berhasil guna.

Pidana penjara mengandung suatu ciri khusus yaitu bahwa sifatnya adalah sementara. Narapidana hanya menjalani hukuman sesuai vonis hakim dan pada akhirnya akhirnya akan kembali ke tengah masyarakat. Oleh karena itu sistem pemenjaraan yang dulunya menekankan pada unsur balas dendam dan penjeraaan sekarang berubah menjadi sistem pemasyarakatan yang menekankan pada unsur pembinaan. Hal itulah yang antara lain menjadi latarbelakang dirubahnya istilah penjara menjadi Lembaga Pemasyarakatan (LAPAS). Kehidupan dalam penjara yang penuh dengan tekanan psikologis bisa berujung pada bunuh diri seperti kejadian 
di Lapas Cipinang (Stress Napi Tewas, 2015). Selain masalah Lapas dan rutan yang overload masalah lain yang menjadi stressor narapidana adalah perasaan sedih pada narapidana setelah menerima hukuman (Mukhlis, 2011). Menjalani kehidupan yang tidak bebas, perasaan malu, sanksi sosial memperburuk dan mengintensifkan stressor sebelumnya. Keadaan tersebutlah yang memicu stress pada narapidana bukan saja mempengaruhi penyesuaian fisik tetapi juga psikologis individu (Mukhlis, 2011).

Stress dalam batas tertentu baik untuk kesehatan kita karena membantu diri kita untuk tetap aktif dan waspada. Namun jika stress yang diterima sangat kuat atau berlangsung lama dan melebihi kemampuan kita untuk mengatasinya maka dapat mengakibatkan distress emosional seperti depresi atau kecemasan, atau keluhan fisik seperti kelelahan dan sakit kepala (Nevid, 2003:140). Dampak jangka panjangnya stress dapat mengakibatkan gangguan pencernaan sampai penyakit jantung (Nevid 2009:136). Melihat betapa buruknya dampak dari stress seharusnya pihak LAPAS melakukan upaya-upaya pencegahan atau pengobatan untuk menangani kasus-kasus stress narapidana. Pasalnya jika keadaan yang menekan narapidana kemudian menjadi stressor yang kuat, tidak dapat tertangani dan teratasi oleh LAPAS maka bisa dimungkinkan akan semakin banyak kasus stress narapidana di LAPAS. Padahal mengingat peran LAPAS sebagai tempat pembinaan seharusnya ketika narapidana keluar dari LAPAS mereka bisa menjadi orang yang lebih baik.

Ada beberapa faktor psikologis yang mengurangi stress diantaranya adalah coping stress. Coping adalah upaya seseorang untuk mengatasi masalah atau menangani emosi negatif yang diakibatkan karena stress (Davidson 2011). Coping dengan cara penyangkalan terhadap stressor, menarik diri dari situasi adalah bentuk coping yang berfokus pada emosi (Nevid, 2009:144). Coping ini bertujuan sebagai upaya untuk mengurangi berbagai reaksi emosi negatif terhadap stress, misalnya dengan mengalihkan perhatian dari masalah (Davidson, 2007). Untuk menangani hal tersebut LAPAS sering dijumpai bentuk kegiatan seperti pelatihan. misalnya pelatihan sablon digital yang dilakukan di Lapas kelas IIA Kediri (50 WBP Lapas, 2015). Selain bertujuan untuk melatih dan menumbuhkan kreativitas, secara tidak langsung bentuk kegiatan semacam ini juga akan mengalihkan perhatian sehingga diharapkan akan mengurangi stress narapidana. Kegiatan lainnya yang sering dilakukan adalah dengan bentuk seni misalnya seni lukis. Seperti yang terjadi di LAPAS Wirogunan Yogyakarta sebanyak 100 warga binaan mengikuti kegiatan melukis bersama dengan takjub "rukun agawe sentosa". Menurut Direktur 
Jenderal Pemasyarakatan Kementerian Hukum dan HAM, I Wayan Kusmiantha Dusak melukis bersama tersebut merupakan salah satu program pembinaan untuk para narapidana. Menurutnya, dengan melukis bisa menjadi jalan para narapidana mengaktualisasikan diri dan berpartisipasi aktif ketika nanti sudah berada di tengah masyarakat (Ketika WargaBinaan, 2015). Selain itu bahkan ada hasil seni dari penghuni LAPAS yang sudah dipasarkan dan terjual seperti yang terjadi di LAPAS kelas III kota Banjar (Warga Binaan Lapas, 2015).

Setiap warga negara berhak mendapatkan pendidikan/pembinaan, baik lewat pendidikan formal maupun pendidikan non-formal. Ellis (Tiya, 2016) menyatakan bahwa pada dasarnya setiap orang manusia memiliki kesanggupan berfikir, maka manusia mampu melatih dirinya sendiri untuk mengubah atau menghapus keyakinan-keyakinan yang irasional menjadi rasional. Dalam hal ini, para narapidana yang beranggapan bahwa dirinya tidak berguna dan tidak memiliki masa depan. Hal tersebut terbentuk oleh pengalaman yang dialami oleh narapidana sehingga terbentuk pemikiran dan keyakinan yang tidak rasional. Cooper dan Duffy (Tiya, 20016) menyebutkan salah satu pembinaan yang terbukti efektif untuk menangani stress adalah pelatihan kognitif. Pelatihan kognitif adalah pelatihan psikologis yang didasarkan pada teori bahwa masalah tersebut dipertahankan oleh disfungsional kognisi dan keyakinan tertentu. Pelatihan kognitif dikembangkan oleh Donald Meichenbaum, yaitu mengkombinasikan prinsip kognitif dan perlakuan dengan metode pendekatan yang singkat. Pelatihannya mengarahkan narapidana untuk memodifikasi fungsi berfikir dengan menekankan peran otak dalam menganalisa. Jika narapidana mampu merubah status pikiran dan perasaannya, narapidana juga diharapkan dapat merubah tingkah lakunya dari negative menjadi positif. Roth dkk (Tiya, 2016) menyatakan bahwa pelatihan kognitif dapat digunakan dalam pelatihan individual dan kelompok, juga dapat digunakan untuk anak-anak, remaja dan dewasa. Pelatihan kognitif juga merupakan treatment yang cukup efisien untuk kasus kecemasan dan stress. Berdasarkan penjelasan di atas dapat disimpulkan pelatihan kognitif adalah suatu treatment untuk membantu individu mengubah cara berpikir irasional menjadi lebih rasional, mempunyai kemampuan mengenali, mengevaluasi keyakinan yang berhubungan dengan emosi, kognisi dan perilaku sehingga individu dapat mengubah perilaku yang mal adaptif menjadi adaptif.

Pelatihan kognitif dalam penelitian ini adalah pelatihan berhitung yang merupakan memberikan manfaat bagi semua orang di masyarakat, termasuk narapidana. Berhitung memiliki empat aspek matematis yaitu mengerjakan operasi hitung penjumlahan, pengurangan, 
perkalian, dan pembagian.sép:Setelah mereka melakukan operasi penjumlahan dan pengurangan selanjutnya mereka mempelajari operasi perkalian dan pembagian. Namun, yang menjadi kajian dalam penelitian ini adalah operasi hitung perkalian. Perkalian merupakan operasi dasar aritmetika utama yang seharusnya yang dipelajari anak-anak setelah setelah mereka mempelajari operasi penambahan dan pengurangan. Perkalian (x) adalah penjumlahan berulang dengan angka yang sama. Operasi hitung perkalian terdapat pada pelajaran matematika yang diberikan di sekolah tingkat dasar. Kurangnya pendidikan merupakan faktor utama yang menyebabkan minimnya pemahaman narapidana terhadap materi operasi hitung perkalian. Sebagian narapidana masih mengalami kesulitan dalam menyelesaikan soal-soal perkalian.

Salah satu permasalahan yang dihadapi narapidana dalam menghitung, misalnya dalam menghitung perkalian maka stimulus yang diberikan harus berupa strategi kemudahan dalam menghitung perkalian, sehingga anak dapat merespon secara positif dan mengerjakan dengan mudah. Penggunaan teknik/metode pengajaran juga sangat penting karena dapat meningkatkan ketertarikan narapidana/warga binaan untuk belajar. Sehingga kemampuan operasi hitung perkalian pada narapidana/warga binaan juga dapat meningkat dalam menyelesaikan konflik emosional, meningkatkan kesadaran diri, mengembangkan ketrampilan sosial, mengontrol perilaku, menyelesaikan permasalahan, mengurangi kecemasan, mengerahkan realitas, meningkatkan harga diri dan berbagai gangguan psikologis lainnya (Mukhlis, 2011). Salah satu metode yang diterapkan dalam melibatkan narapidana secara aktif adalah menggunakan model pembelajaran Jarimatika. Jarimatika adalah gabungan dari kata jari dan aritmetika, merupakan suatu teknik menghitung matematika dengan menggunakan alat bantu jari.

Terapi kognitif dengan pelatihan jarimatika pada penelitian ini dilakukan secara kelompok. Losyk (2007) mengemukakan bahwa pendekatan kelompok secara signifikan dapat memberi manfaat pada narapidana dengan cara bertukar pikiran atau berbicara pada orang lain yang pernah mengalami permasalahan yang sama. Dari hasil wawancara dengan Kepala Pekerja Sosial menyatakan ucapan terima kasih kepada penyelenggara kegiatan pelatihan dan berharap agar diadakan pelatihan berhitung tingkat lanjut. Ia juga menyampaikan bahwa ada narapidana yang setiap seminggu sekali dia selalu mengajarkan teknik berhitung kepada anaknya. Kepala Pekerja Sosial juga menyatakan penguasaan teknik jarimatika tidak membutuhkan banyak waktu dan teknik ini tidak mudah lupa karena dilakukan langsung oleh narapidana dan menepiskan anggapan bahwa berhitung itu sulit dan menjengkelkan. 
Sebelum jari digunakan untuk menghitung, terlebih dahulu harus dipahami cara penggunaannya dengan begitu mudah untuk dipelajarinya dan penguasaannya tidak membutuhkan waktu lama. Cara cepat ini adalah latihan mental: melatih memori dan memancing imajinasi, membantu membuat pikiran tetap fleksibel dan siaga. Teknik jarimatika ini lebih efektif karena tidak menggunakan alat bantu apapun, kecuali dengan jari. Pembelajaran ini akan membantu kreatifitas narapidana/warga binaan, karena dengan kekuatan angka dapat dibangun diantaranya melalui jari tangan yang mengajarkan berhitung dengan cepat. Jarimatika mampu meningkatkan daya ingat narapidana/warga binaan karena metode jarimatika adalah hal yang dilakukan dan dilihat oleh narapidana/warga binaan secara langsung. Jika narapidana/warga binaan sudah menyenangi pelajaran matematika (khususnya berhitung) apalagi berhitung dengan cepat, maka akan dapat mengoptimalkan fungsi "otak kiri” yang bersifat "akademis" dan "otak kanan" yang bersifat "kreatif" sehingga akan mampu meningkatkan daya ingat, reaksi, konsentrasi, kreatifitas dan percaya diri dalam mengatasi berbagai masalah

Berdasarkan perspektif di atas antara matematika dengan psikologi bisa diintegrasikan diantara keduanya ke dalam bentuk penanganan terhadap penurunan tingkat stress. Dalam hal ini peneliti bermaksud meneliti "Pengaruh Pelatihan Jarimatika Terhadap Tingkat Stress Bagi Narapidana Lembaga Pemasyarakatan (LAPAS) Kelas IIB Rangkas Bitung”.

\section{METODE PENELITIAN}

Penelitian ini menggunakan penelitian quasi-experiment. Desain yang digunakan adalah control group design with pre-test and post-test yaitu desain eksperimen yang menggunakan dua kelompok yang terdiri dari kelompok kontrol dan kelompok eksperimen (Azwar, 2012). Desain eksperimen penelitian ini menggunakan Pretest-posttest Control Croup Design yaitu dengan melakukan pengukuran sebelum (pretest) dan sesudah (posttest) dan pemberian treatment pada kelompok eksperimen. Pada desain ini juga dilakukan randomisasi sebagai kontrol proactive history untuk menyetarakan (Liche, Aris, \& Bernadett, 2011).

Tabel 1. Rancangan Penelitian

\begin{tabular}{lccc}
\hline Kelompok & Pretest & Perlakuan & Posttest \\
\hline Eksperimen & $\mathrm{O}$ & $\mathrm{X}$ & $\mathrm{O}$ \\
Kontrol & $\mathrm{O}$ & - & $\mathrm{O}$ \\
\hline
\end{tabular}

Keterangan:

$\mathrm{O}=$ Pemberian instrument Pretes-Posttest pada kelompok eksperimen dan kontrol 
$\mathrm{X}=$ Perlakuan

$-\quad=$ Tidak diberi perlakuan

Subjek dalam penelitian ini yaitu narapidana Lapas kelas IIB Rangkas Bitung. Waktu penelitian dilakukan pada bulan Agustus 2019. Pelatihan dilakukan 2x pertemuan hanya seminggu dan durasi waktu 60-90 menit setiap sesi. Penelitian ini menggunakan skala stress yang disusun berdasarkan teori yang dikemukakan oleh Tylor (2003) dan juga disebutkan oleh Davis dan Nelson yang menjabarkan stress ke dalam empat aspek yaitu aspek emosional (perasaan), Kognitif (pikiran), Perilaku Sosial, Fisiologis dalam bentuk skala Likert yang terdiri dari 37 item valid dan reliabilitas sebesar 0,888. Skala ini terdiri dari empat alternatif jawaban yakni: sangat setuju (SS), setuju (S), tidak setuju (TS), dan sangat tidak setuju (STS).

Subyek sejumlah 50 narapidana yang terbagi menjadi 2 yaitu kelompok eksperimen dan kelompok kontrol yang masing-masing kelompok terdiri dari 25 narapidana. Penelitian ini menggunakan analisis untuk melakukan uji hipotesis dengan menggunakan teknik uji t yaitu paired sample t-test. Teknik ini digunakan untuk melihat pengaruh pelatihan jarimatika terhadap penurunan stres bagi narapidana yang dilihat dari perbedaan antara skor pretest dan posttest.

\section{HASIL DAN PEMBAHASAN}

Secara deskripsi melalui bentuk kategori tingkat stress pada narapidana penelitian. Berikut disajikan Tabel identifikasi kategori tingkat stress narapidana sebelum pelatihan jarimatika.

Tabel 2. Identifikasi Awal Pengkategorian Tingkat Stress Narapidana

\begin{tabular}{lcc}
\hline \multicolumn{1}{c}{ Kategori Tingkat Stres } & Jumlah & Persentase (\%) \\
\hline Normal & 3 & 6 \\
Stress Ringan & 13 & 26 \\
Stress Sedang & 19 & 38 \\
Stress Berat & 13 & 26 \\
Stress Sangat Berat & 12 & 24 \\
\hline Total & 50 & 100 \\
\hline
\end{tabular}

Hasil penelitian menunjukkan bahwa sebagian besar narapidana berada pada kondisi stres mulai dari stres ringan sampai stres berat. Berdasarkan Tabel 2 diketahui bahwa identifikasi tingkat stress sebelum dilakukan pelatihan jarimatika yaitu jumlah narapidana yang mengalami stres normal sebanyak 3 responden (6\%), stres ringan sebanyak 13 responden (26\%), stres sedang sebanyak 19 responden (38\%), stress berat sebanyak 13 responden (26\%) dan stress sangat berat sebanyak 12 responden (24\%).

Selain uji hipotesis, pada penelitian ini juga akan dilakukan uji prasyarat, yaitu uji 
normalitas. Uji normalitas dilakukan untuk mengetahui apakah nilai residu yang diteliti memiliki distribusi normal atau tidak. Uji normalitas dapat digunakan dengan menggunakan nilai Kolmogorov-Smirnov. Untuk pengolahan data, perhitungan ini dilakukan dengan menggunakan program SPSS.

Tabel 3. Uji Normalitas

\begin{tabular}{cccccccc}
\hline \multirow{2}{*}{ Tingkat } & \multirow{2}{*}{ Kelompok } & \multicolumn{2}{c}{ Kolmogorov-Smirnov } & \multicolumn{3}{c}{ Saphiro Wilk } \\
\cline { 2 - 7 } Stress & & Statistic & df & Sig. & Statistic & df & Sig. \\
\cline { 2 - 7 } & Pretest & 0,144 & 23 & 0,200 & 0,943 & 23 & 0,666 \\
& Posttest & 0,225 & 23 & 0,200 & 0,898 & 23 & 0,318 \\
\hline
\end{tabular}

Hasil uji asumsi normalitas di atas menggunakan Kolmogorov-Smirnov bahwa nilai yang diperoleh sebelum dan sesudah diberikannya perlakuan memiliki nilai yang normal, dimana nilai sebelum adanya perlakuan memiliki nilai p sebesar 0,200>0,05 artinya, sebaran data stres sebelum perlakuan adalah normal. Dan setelah perlakuan memiliki nilai p sebesar 0,200 >0,05 artinya, sebaran data stres setelah perlakuan adalah normal. Setelah dilakukannya uji asumsi normalitas, barulah peneliti melakukan uji hipotesis yang dilakukan menggunakan paired sample t-test.

Tabel 3. Hasil Uji Paired Sample t-test

\begin{tabular}{|c|c|c|c|c|c|c|c|c|c|}
\hline & & \multirow[b]{3}{*}{ Mean } & \multirow{3}{*}{$\begin{array}{c}\text { Std. } \\
\text { Deviation }\end{array}$} & \multirow{3}{*}{$\begin{array}{l}\text { Std. } \\
\text { Error } \\
\text { Mean }\end{array}$} & \multicolumn{2}{|c|}{ 95\% Confidence } & \multirow[b]{3}{*}{$\mathrm{t}$} & \multirow[b]{3}{*}{$\mathrm{df}$} & \multirow{3}{*}{$\begin{array}{c}\text { Sig. } \\
(2- \\
\text { tailed) }\end{array}$} \\
\hline & & & & & \multicolumn{2}{|c|}{$\begin{array}{l}\text { Interval of the } \\
\text { Difference }\end{array}$} & & & \\
\hline & & & & & Lower & Upper & & & \\
\hline Pair 1 & $\begin{array}{l}\text { Sebelum- } \\
\text { Setelah }\end{array}$ & 5,286 & 6,237 & 2,358 & -6.573 & $-2,227$ & $\begin{array}{c}- \\
4,342\end{array}$ & 23 & .038 \\
\hline
\end{tabular}

Analisis hipotesis II hasil uji Paired Sample t-test menunjukkan nilai thitung $=-4,324<$ $\mathrm{t}_{\text {tabel }}=-2,682$. Karena $\mathrm{t}_{\text {hitung }}<-\mathrm{t}_{\text {tabel }}$ maka $\mathrm{H}_{0}$ ditolak. Hal ini menunjukkan adanya perbedaan tingkat stress sebelum dan sesudah perlakuan pada kelompok eksperimen atau dengan kata lain pada uji Paired Sample t-test menunjukkan nilai Sig. (2-tailed) $=0.038<0,05$ atau artinya bahwa terdapat perbedaan tingkat stres yang signifikan antara sebelum dan sesudah dilakukan pelatihan jarimatika.

Hasil analisis menunjukkan ada beberapa faktor yang mempengaruhi keberhasilan responden mempraktikkan jarimatika yang selanjutnya berkorelasi terhadap penurunan stress dipengaruhi oleh keaktifan responden untuk berlatih dan mengulang apa yang telah dipelajari selama pelatihan dalam kehidupan sehari-hari. Selain itu diperlukan pula karakteristik keterbukaan pada pengalaman, motivasi, dan sikap 'menjadi' alih-alih sekedar 'melakukan' 
(Kabat-Zinn, 1990, hlm. 95). Hasil pengukuran pada setiap aspek stres menunjukkan penurunan paling signifikan terdapat pada domain fisik. Hal ini nampak dari pengukuran posttest dimana rerata stress aspek fisik mengalami penurunan terbesar dibandingkan rerata aspek lainnya, dilanjutkan dengan aspek emosi, perilaku, dan yang terakhir aspek kognitif. Penjelasan lebih lanjut mengenai deskripsi penurunan stres per-aspek dapat dilihat pada tabel berikut:

\begin{tabular}{lrrr}
\multicolumn{4}{c}{ Tabel 4. Statistik Deskriptif Per-Aspek Variabel Stres } \\
\hline \multicolumn{1}{c}{ Aspek } & $\begin{array}{c}\text { Mean Skor } \\
\text { Pretest }\end{array}$ & $\begin{array}{c}\text { Mean Skor } \\
\text { Posttest }\end{array}$ & Selisih \\
\hline Stress & 78,60 & 68,60 & 10,0 \\
Emosional & 19,60 & 16,80 & 2,8 \\
Kognitif & 21,00 & 19,20 & 1,8 \\
Perilaku Sosial & 16,80 & 14,40 & 2,4 \\
Fisiologis & 21,20 & 18,20 & 3,0 \\
\hline
\end{tabular}

Berdasarkan data di atas menurut analisis aspek stress menurut Taylor (2003) membagi gejala stres menjadi 4: gejala emosi, kognisi, gejala sosial, dan gejala fisik. Gejala emosional (Perasaan) responden memiliki rataan pretest sebesar 19,60, rataan posttest sebesar 16,80 dan selisih sebesar 2,8. Gejala emosional ini meliputi cemas, murung, rasa tidak mampu untuk melakukan sesuatu, perasaan marah, merasa ketakutan. Gejala kognisi pada responden memiliki rataan pretest sebesar 21,00, rataan posttest sebesar 19,00 dan selisih 1,8. Gejala kognisi ini meliputi takut gagal, tidak dapat berkonsentrasi, ceroboh, rasa khawatir, penghargaan diri yang kurang. Gejala sosial pada responden memiliki rataan pretest sebesar 16,80, rataan posttest sebesar 14,40 dan selisih sebesar 2,4. Gejala sosial ini berakibat seorang yang mengalami stres menjadi sulit bekerja sama, gugup ketika berbicara dengan teman, tidak tenang, dan bertindak sesuka hati. Gejala fisik pada responden memiliki rataan pretest sebesar 21,20, rataan posttest sebesar 18,20 dan selisih sebesar 3. Gejala fisik ini mengakibatkan berkeringat, detak jantung meningkat, merasa gugup, gemetaran, mudah lelah, sering buang air kecil, susah tidur, sakit kepala, tekanan darah tinggi.

Rata-rata skor stres setelah dilakukan pelatihan jarimatika adalah 68,80. Berdasarkan kategori tingkat stres rata-rata skor stres setelah perlakuan masuk ke dalam kategori normal. Salah satu manajemen stres adalah berbagai macam pelatihan yang dilakukan lembaga untuk bekal/keterampilan narapidana selepas keluar dari LAPAS. Salah satu bentuk pelatihan jarimatika adalah untuk manipulasi pikiran mengurangi komponen fisiologis dan emosional stres bagi narapidana. Teknik pelatihan jarimatika ini akan mengurangi ketegangan dan parameter fisiologis akan berubah. Berdasarkan hasil penelitian ini tingkat stres mengalami 
penurunan setelah dilakukan pelatihan jarimatika yang dilakukan peneliti selama satu minggu. Setelah dilakukan pelatihan jarimatika di dapatkan data sebagian besar narapidana mengalami penurunan skor stres. Hal ini sesuai dengan pernyataan Greenberg dalam Mashudi (2012) bahwa usaha melakukan pelatihan/keterampilan akan memberikan hasil setelah dilakukan minimal sebanyak 2-3 kali latihan.

Data selisih aspek menunjukkan perubahan paling signifikan ada pada aspek fisiologis dengan total nilai selisih yaitu 3. Secara umum hal ini menjadi penguat adanya pelatihan jarimatika yang berpengaruh secara signifikan untuk menurunkan tingkat stress khususnya pada aspek fisiologis. Alasannya, setelah narapidana mendapatkan pelatihan jarimatika berupa pengajaran operasi perkalian ini, mereka mampu mengajarkan pemahaman subjek tentang konsep operasi hitung perkalian kepada anak, sanak dan keluarganya di luar. Dalam hal ini materi yang disampaikan, membukakan pandangan baru yang lebih positif sebagai jalan untuk menemukan harapan. Harapan baru ini menjadikan mereka lebih tenang karena stressor yang mereka timpa misalnya kekhawatiran akan masa depan mulai terkikis. Ketenangan inilah yang berpengaruh pada aspek fisiologis misalnya detak jantung yang mulai normal, tidak lagi cemas sehingga masalah dengan tidur mulai menurun (indikator fisiologis).

Perubahan atau selisih aspek paling besar kedua dengan selisih skor 2,8 adalah aspek emosional dilanjutkan aspek paling besar ketiga perilaku sosial dengan selisih skor 2,4. Ketika subjek tidak rileks, cemas, putus asa, pesimis dan khawatir akan hidupnya otomatis akan berpengaruh dalam perilaku sosialnya misalnya menjadi enggan bekerja sama. Setelah mereka mendapatkan pemahaman yang lebih positif tentang hidupnya subjek menjadi lebih fresh, senang, lebih bahagia, dan tidak lagi merasa kesepian. Keempat aspek ini adalah satu kesatuan sehingga hubungan diantaranya memang sangat kompleks. Misalnya dalam aspek perilaku sosial yaitu indikator kesusahan untuk rileks maka sangat berhubungan dengan indikator cemas dalam aspek emosional. Kemudian indikator murung dalam aspek emosional juga sangat berkaitan dengan indikator enggan untuk bekerja sama dalam aspek perilaku sosial. Oleh karena itu perubahan yang terjadi pada seluruh aspek tidak bisa lepas satu sama lain. Dengan bertambahnya wawasan baru pada subjek, akan berpengaruh pada tingkat kepercayaan diri subjek ketika sudah bebas nanti. Hal ini menjadi berhubungan karena data mengenai selisih point pada setiap item menunjukkan bahwa selisih paling tinggi selanjutnya adalah item tentang penghargaan atas diri. Setelah mengikuti pelatihan berdasarkan data selisih setiap item, subjek 
merasa lebih menghargai atas dirinya. Hal ini terjadi karena subjek merasa lebih percaya diri dari sebelumnya.

Pada selisih aspek paling signifikan setelah aspek perilaku sosial yaitu aspek kognitif dengan selisih 1,8. Selisih pada aspek kognitif ini juga menjadi temuan sekaligus bukti bahwa pelatihan jarimatika seperti yang dijelaskan sebelumnya berpengaruh terhadap pemahaman subjek tentang konsep matematis. Pasalnya jika kita analisis ketika mereka mendapatkan pemahaman hidup yang lebih baik, mereka menjadi lebih baik dalam menghargai dirinya. Data pada angket ini menjadi penguat bahwa subjek menjadi lebih baik dalam menghargai diri dan memandang hidupnya. Adanya penghargaan diri yang lebih baik membuat subjek lebih optimis, tidak takut gagal dan tidak lagi khawatir akan masa depannya.

Berdasarkan hasil penelitian, pelatihan jarimatika menjadi salah satu variabel yang penting, dalam mengurangi tingkat stress narapidana. Melalui kegiatan pelatihan jarimatika, narapidana lebih mampu mengelola stres yang sedang dialaminya. Pelatihan jarimatika, menjadikan partisipan lebih adaptif terhadap ujian hidup, sehingga mereka tidak melakukan perbuatan yang merugikan diri sendiri maupun orang lain. Dalam hal ini Silk (Renanita, 2012) menyatakan bahwa, stres yang tidak dikelola dengan baik, dapat menjerumuskan remaja ke dalam perilaku yang menyimpang seperti tindak kecenderungan kenakalan remaja.

Faktor lain yang mendukung keberhasilan penelitian, adalah penyusunan materi pelatihan yang sesuai dengan aspek jarimatika. Selain itu, dalam pelatihan jarimatika terdapat ice breaking. Kegiatan ini dimaksudkan untuk mendorong narapidana agar dapat mengikuti pelatihan dengan perasaan nyaman dan santai, sehingga narapidana dapat terlibat sepenuhnya untuk mengikuti jalannya pelatihan. Kondisi rileks yang diciptakan, dapat membantu partisipan untuk tetap dalam kondisi optimal. Selain itu, variasi metode dalam pelatihan jarimatika mendukung pula keberhasilan dalam penelitian ini. Metode ceramah, diskusi, latihan atau penugasan, permainan, presentasi, menonton, dan praktek berhasil memberikan nuansa lebih hidup, rileks, ceria, menantang, santai dan, bersemangat selama berlangsungnya pelatihan. Peran aktif partisipan dalam pelatihan jarimatika selama dua hari turut mendukung keberhasilan pelatihan.

Adapun yang menjadi kelemahan dalam penelitian ini adalah, durasi waktu yang sangat singkat dalam setiap sesi pelatihan yang diberikan, sehingga dapat mengurangi penghayatan terhadap isi materi yang dipelajari partisipan. Selain itu, peneliti tidak mengukur tingkat stress 
narapidana, sebelum dan sesudah pelatihan diberikan, mengingat keterbatasan waktu. Hal ini sebenarnya penting dilakukan, untuk membuktikan bahwa narapidana secara terukur memiliki tingkat stress tertentu, terkait tindak kecenderungan tingkat stress yang dilakukannya.

\section{KESIMPULAN}

Berdasarkan hasil analisis statistik yang dilakukan, terbukti adanya perbedaan antara skor pre-test, dan post-test pada narapidana terhadap adanya pelatihan jarimatika. Sehingga dapat disimpulkan bahwa, pelatihan jarimatika dapat menurunkan tingkat stress meskipun tidak signifikan dan beberapa saran yang dapat diberikan adalah (1) Kepada kalangan LAPAS adanya perubahan positif dalam penurunan tingkat stress bagi narapidana, LAPAS diharapkan untuk senantiasa melakukan evaluasi terhadap kondisi narapidana, khususnya jika terdapat indikasi stress yang sedang dialaminnya. Dalam hal ini LAPAS dapat mengupayakan tindakan maupun situasi kondusif untuk mencegah maupun mengatasi kondisi stress yang sedang dialami narapidana, salah satunya melalui pelatihan jarimatika. Hal ini diharapkan agar narapidana terhindar dari tingkat stress yang sifatnya merugikan. (2) Untuk penelitian selanjutnya perlu mengkaji aspek spiritual secara lebih mendalam, khususnya terkait penerapannya dalam konteks pelatihan jarimatika pada operasi hitung perkalian. Dalam hal ini, durasi waktu yang lebih panjang perlu ditambah agar partisipan memiliki waktu dan kesempatan yang memadai untuk lebih memahami dan menghayati materi yang dipelajari dalam pelatihan. Harapannya adalah agar materi pelatihan dapat dihayati dan diterapkan di LAPAS maupun ketika di luar. Penelitian selanjutnya juga dapat mengukur tingkat stress narapidana, untuk melihat secara lebih rinci mengenai kondisi stress yang dirasakan, baik sebelum maupun sesudah pelatihan diberikan. Selain itu, durasi pelatihan dapat diperpanjang agar proses pelatihan memiliki pengaruh yang lebih besar.

\section{REFERENSI}

50 WBP Lapas Kediri. (2015). Info Pas Kanat KabarLapas. [Online]. Tersedia di: http://www.lapaskediri .com/2015.

Azwar, S. (2012). Metode Penelitian. Yogyakarta: Pustaka Pelajar.

Davidson, G. C., Neale, J. M., and Kring, A. M. (2011). Psikologi Abnormal. Jakarta: PT Raja Grafindo Press. 
Harapan Rakyat. (2015). Warga Binaan Lapas Banjar Terus Berkarya Meski dalam Penjara. [Online]. Tersedia di: http://www.harapanrakyat.com/2015

Jeprina, T. (2016). Pelatihan Kognitif Perilaku untuk Menurunkan Tingkat Depresi. Laporan Penelitian (tidak diterbitkan). Semarang: Pusat Penelitian IAIN Walisongo.

Kabat-Zinn, J. (2003). Mindfulness-based Interventions in Context: Past, Present, and Future. Clinical Psychology: Science and Practice, 10, hlm. 144-156.

Korannonstop. (2015). Stress, Napi Tewas Bakar Diri di Kamar Sel Lapas Cipinang. [Online]. Tersedia di: http:// korannonstop.com/2015.

Liche, S., Aries. Y, dan Bernadett, N.S. (2011). Psikologi Eksperimen. Jakarta: PT Indeks.

Losyk, B. (2007). Kendalikan Stres Anda: Cara Mengatasi Stres dan Sukses di Tempat Kerja. Jakarta: Gramedia Pustaka Utama.

Mashudi, Farid. (2012). Psikologi Konseling. Jogjakarta: Diva press

Muhklis. (2011). Pengaruh Membatik Terhadap Depresi Narapidana. Journal of Consulting and Clinical Psychology, 71, 404-409.

Nevid, E.S., dkk. (2009). Psikologi Abnormal. Jakarta: Erlangga.

Renanita, T., Hakim, M. A., dan Yuniarti, K. W. (2012). Vulnerable factors of sadness among adolescents in Indonesia: an exploratory indigenous research. Humanitas, Vol. IX, No. 1, hlm. 1-11. 